\title{
Research on Individualized Education of University Students from the Perspective of Higher Education Management
}

\author{
Yong Liu, Quan Wen \\ Gannan Medical University, Ganzhou, 341000, China
}

Keywords: Individualized education, University students, Higher education management

\begin{abstract}
The ultimate goal of higher education management is to promote the all-round development of college students, and the individualized development is an important part of the all-round development of university students. This paper analyzes the current situation of the individualized development of university students under the shackles of higher education management in China, and gives corresponding countermeasures and suggestions, including updating education concept, strengthening teaching management and perfecting cultivation system, to provide some references for the relative researchers.
\end{abstract}

\section{Introduction}

In recent years, more and more scholars have explored the development of college students' personality in China. Many colleges and universities have carried out beneficial exploration and Practice on the individualized education of college students. On the one hand, it has greatly enriched the cultural life of the amateur college students, students can more quickly get a lot of information through the network; on the other hand, disorderly and virtual network for college students to establish a correct outlook on life and values have a negative impact. In view of this phenomenon, it is necessary to reconsider the personality development of college students and advocate the harmonious development of dominant personality and recessive personality. The scope of overall development should include two parts: the general development of human beings and the development of personality. The development of general development is often mentioned in our daily life aspects. Personality development refers to the development of a person's creativity and uniqueness. Personality development is the inevitable requirement for all-round development of human beings, and all-round development is the goal of personality development. General development through the primary school, junior high school, high school system education has formed the inherent training style. Although this training method has some positive significance, but the training of people like the product line - monotony, no personality. The important task of colleges and universities is to provide support and guarantee for the personality development of college students, to realize the all-round development of college students. The main object of education management is the goal of college students, education management is a way to cultivate college students, stimulate the development potential in all aspects of college students' morality.

\section{Restrict Forms of Individualized Education of University Students by Higher Education Management}

Inaccurate Education Objectives. The particularity of the emergence and development of college students' recessive character, development and influence of it is highly dependent on the Internet, most of the students have spare time to swim in the network world, to obtain information from the virtual world, self-realization. However, the educational administrators in early universities in China do not have enough knowledge about the impact of new media technology, especially the 
Internet on college students. The goal of higher education is to cultivate all-round development of new students, the college students' personality, especially the implicit personality is obviously not enough attention. college students are trained as "products" produced in the assembly line, and standardized training is carried out. This training mode makes the students' personality not be publicized, and has no unique personality advantages. China's higher education goal is to cultivate high-quality personnel of comprehensive development of students' morality. However, at present, many colleges and universities are inclined to cultivate intelligence, ignore other aspects of quality education, so that students' personality development is limited. overall, the education of colleges and universities pays attention to the common education, ignores the individuality education; pays attention to the unified education, neglects to teach students in accordance with their aptitude; pays attention to the average achievement, neglects the specialty development. In this mode of education, students' personality is very difficult to obtain the full development, to a certain extent, stifle innovation ability of students since the resumption of college entrance examination system, the college entrance examination is the unified outline, unified teaching material, unified proposition, made into university students are from a mold carved out, the lack of personality if the higher education continues to follow the traditional mode of education, students are the same in all aspects, cannot meet the social needs for talents so as to the development of personality training standards, make talents meet the needs of the community.

Single Teaching Methods. At present our country colleges and universities began to pay attention to the development of personality of college students, but in actual operation, many colleges and universities are simply that the students' personality development way is to open several electives, adding several quality development credits, organizing several classroom teaching practices, or directly to the implementation of the credit system is an important means of students' personality the development of the. However, the credit system in China's colleges and universities is not a real credit system, it is the credit system under the academic year system, the credit system has not been really implemented, and did not play its due advantages. Thus, the development of students' explicit personality needs is difficult to meet, the original development of the invisible personality is more difficult to meet the demand. The credit system education mode is adopted in Colleges and universities in china. However, in the implementation process, the credit system has not played its due effect, but it has become another form of the school year system. Although colleges and universities have elective and compulsory education system, but due to the lack of attention to elective courses, elective courses are far less than required courses. At the same time, elective courses still exist problems, some elective courses is popular with the students, the students who want to attend a lot, but because the teachers less, to accommodate the number of courses, many students cannot participate in the study of this course, the students' personality development cannot meet the needs of some popular there are few students in courses, takes up a lot of teaching resources, so it is necessary to adjust the curriculum resources, to meet the needs of the development of students' personality, personality education lags behind the development status change. These management systems did not touch the depth of their thoughts, and did not form a truly effective standard and binding mechanism, which led to the existence of various contradictions for a long time. This is very easy to happen a variety of illegal and discipline things, affecting the school's education management.

Backward Management Models. The core of China's higher education is to cultivate the talents of all aspects, but now most of the overall development of China's higher education for the students do not pay attention to, mainly is the importance of common, overall is qualified, but ignore the personality, and It differs from man to man. Current colleges and universities for college students' personality differences in cognitive deficiencies, inadequate attention to personality of students lack the corresponding incentive measures or guidance methods, the concrete manifestation is oppressed, problems encountered at a loss what to do. Although a variety of related institutions of higher learning in the teaching management system has been improved, but most of them are present on the surface, with some constraints norms mandatory means of students, students not deep thoughts. It is due to a variety of potential defects in higher education, and cannot be solved in time, causing all kinds of violation of school rules, even lawlessness phenomenon. This will have a considerable 
impact on students' normal life and learning. Although the universities do not deny the individual differences of students, but the lack of personalized education, there is no in-depth study on individualized education management, the lack of relevant policies to encourage individual development of students, so that students in the school lack shows the character of the stage do not attach importance to such attitude will bring two results, one is the students the personality is exhausted, common personnel eventually become featureless, another result is that the students appear rebellious, although failed to make higher education universities also embarked on reforms of common management mode, but since there are no of the core management model for reform, so the current university management mode is relatively rigid, lack of activity.

\section{Suggestions on Individualized Education of University Students from the Perspective of Higher Education Management}

Update Education Concept. The reform of education concept can fundamentally change the educational model of colleges and universities, and make the students' personality get better development. There are two main points to be innovated: one is to set up the educational idea of "people first", and the other is to deal with the relationship between personality development and overall development. college students are the object of higher education activities, is also the subject of educational activities, so in the education administration to establish a people-oriented, student-centered education concept, give students enough freedom and democracy, the development of students' personality is not restricted. Democracy is the basis for the development of personality, freedom is the premise of personality development, both are indispensable. Set up people oriented education concept, pay attention to the personality differences of college students. First, we should understand the specialty of college students, and give guidance to the development of this special ability, so that students can use scientific and reasonable way to develop expertise. Secondly, to help students to identify themselves, find their own good areas, and help students improve, so that students can find their own unique aspects, to obtain the development of personality. Colleges and universities in the implementation of the people-oriented management philosophy, but also pay attention to the characteristics and laws of physical and mental development of college students, develop training programs, corresponding to their aptitude, cultivate students' unique personality, ready to work for the college students into the community. Overall development and personality development are dialectical unity, and comprehensive development is to fully exploit human potential. Therefore, the development of all-round development is the process of the formation of personality process of personality is the core of all-round development, is the beginning of a comprehensive development of education, is the starting point of college students' all-round development of personality education to a certain extent, the development of the formation will students will explore on their own areas of interest, enrich their own the knowledge, improve their own knowledge system, and finally achieve self-value goal.

Strengthen Teaching Management. The goal of higher education is to train advanced talents, but there are still great differences between the trained talents and expectations. The reason is that the students in the university learn more theoretical knowledge, lack of social practice needs the ability of practice ability and innovation ability, knowledge and some courses have learned, it is often impractical. This not only wastes the educational resources, but also wastes the valuable learning time and energy of the college students. If you want to learn but not learn, do not want to learn to learn, the more negative the personality development of students so that schools should reform the current higher education management system, will be included in the training of college students' personality development and development goals, this is the quality of education in colleges and universities, but also the social personnel training requirements. Credit system management is an educational management mode which is beneficial to teaching students in accordance with their aptitude and developing their personality. The advantage of this system is that it can flexibly meet the needs of students' personality development, such as interest in learning. Its flexibility lies in: one is to break the academic year course closed, do curriculum resource sharing; two is to meet the requirement of 
students' individuality development; three is conducive to promoting the development of student's personality, such as the first graduate students can learn fast, slow learners can slow the graduation, more conducive to individualized teaching, also to adapt to college students' entrepreneurship need. Therefore, the credit system has become a common form of education management in Colleges and universities in various countries. Teachers and students are seekers of knowledge, there is no level distinction in the face of learning, teachers guide students, students can also affect teachers truly Teaching benefits teachers as well as students. In the classroom between teachers and students can discuss with each other, teachers should support and each one airs his own views to encourage students to think independently, dare to ask questions, because the creative consciousness originates from the question, only to find the problem and put forward the problems of people can have the impulse to create.

Perfect Cultivation System. In the new media era, the rapid development of college students' implicit personality is a subject that all managers of colleges and universities must face. Innovative management mechanism is the only way to ensure the healthy and stable development of college students. First, the management mechanism must respect the language habits of college students. The popularity of network language and the acceptance of college students are very high. Managers should accept this language habit and use these languages, so that college administrators can share common language with students. Management mechanism must respect the behavior habits of college students. college students' personal independence of conduct, pioneers, individuality is their labels, managers in the development system, to the needs of students as the starting point, to create a good educational environment, encourage students to express themselves, the development of personality. Management mechanism must respect the subjective status of college students. To develop students' personality management norms, we should fully listen to the opinions of students, create a democratic atmosphere, and provide a rich system of soil for the development of college students' personality. Establish a high quality, understand the network, young teaching team. A good first step is theory teaching, teachers' teaching level is the key to determine the effect of students' learning quality, the management will be accepted in the daily life, students generally stronger affinity for young teachers to organize the teaching work. On the one hand, in the daily management practice have proved that they can communicate with students to communicate, easily accepted by the students; on the other hand, they are can quickly become familiar with and master the internet and new media technology. Such teachers can use the language and behavior to communicate with students.

\section{Conclusion}

The development of students' personality is the core of quality education. The mode of education reform of higher education management of college students' individual development is imperative, only through the cultivation of students' individual development, can cultivate social needs of modern talents, promote the students' comprehensive quality improvement, let the students become the talents needed by the society.

\section{References}

[1] Li Wei. A Report on the Development of Individualism of Colleges Students Based on College Administration [J]. Journal of Hubei Correspondence University, 2015, 28(1): 25-26.

[2] Fan Jie. Research on Individualized Service of Ideological and Political Education in Universities in Big Data Era [J]. Journal of Changchun University, 2017, 27(6): 47-50.

[3] Zhou Jin. Action Factors of Individualized Education in World-class Universities and Its Insights [J]. Research in Higher Education of Engineering, 2017(5): 96-101+124.

[4] Yuan Xu. Exploration on Individualized Education for University Students in the Background of Big Data Era [J]. The Science Education Article Collects, 2015(2): 45-46. 